\title{
RANCANG BANGUN APLIKASI PENGADAAN BARANG DAN JASA BERBASIS WEB PADA BMKG
}

\author{
Shendyko Wicaksono, Martua Hami Siregar, Maysaroh \\ STMIK Nusa Mandiri Jakarta Indonesia \\ Universitas Bina Sarana Informatika Jakarta, Indonesia \\ Universitas Bina Sarana Informatika Jakarta, Indonesia \\ shendy@ rocketmail.com, martua.mhe@bsi.ac.id, maysaroh.msy@bsi.ac.id
}

\begin{abstract}
ABSTRAK
Dalam proses pengelolaan dokumentasi surat perintah kerja pengadaan BMKG masih belum maksimal salah satunya banyak yang tercecer atau terjadinya duplikasi data dan sering terjadi human error. Hal ini menjadi sebuah kendala atau masalah dalam hal peningkatan kualitas pengelolaan dokumen surat perintah kerja pengadaan terutama didalam era teknologi dan informasi. Aplikasi Pengadaan Barang dan Jasa berbasis web ini, dapat mempermudah Pejabat Pengadaan (PP) dan Pejabat Pembuat Komitmen (PPK) dalam proses manajemen dokumen pengadaan dan pembuatan laporan dengan menggunakan bahasa pemrograman PHP dan MySQL sebagai database. Desain Aplikasi Pengadaan Barang dan Jasa berbasis web ini terlihat user friendly. Dapat mempercepat proses pengadaan barang dan jasa. Dapat mempercepat proses pembuatan laporan bulanan. Sistem yang dirancang menggunakan 2 hak akses yang diberikan kepada Admin, dan User.
\end{abstract}

Kata Kunci: Pengadaan Barang dan Jasa, PHP, MySQL, User Friendly

\begin{abstract}
In the process of managing the documentation for the work order for BMKG procurement, it is still not optimal, one of which is that there are many scattered or duplication of data and frequent human errors. This becomes an obstacle or problem in terms of improving the quality of document management for procurement work orders, especially in the era of technology and information. This web-based application for procurement of goods and services can make it easier for Procurement Officers (PP) and Commitment Making Officers (PPK) in the process of procurement document management and report generation using the PHP programming language and MySQL as the database. This web-based application design for procurement of goods and services looks user friendly. Can speed up the process of procuring goods and services. Can speed up the process of making monthly reports. The system is designed using 2 access rights given to Admin and User.
\end{abstract}

Keywords: Procurement of Goods and Services, PHP, MySQL, User Friendly

\section{PENDAHULUAN}

Badan Meteorologi, Klimatologi, dan Geofisika (disingkat BMKG), sebelumnya bernama Badan Meteorologi dan Geofisika (disingkat BMG) adalah Lembaga Pemerintah Non Departemen Indonesia yang mempunyai tugas melaksanakan tugas pemerintahan di bidang meteorologi, klimatologi, dan geofisika. Pada BMKG terdapat sebuah bagian khusus yang bertugas mengelola Pengadaan. Dalam penyimpanan dan pengolahan pengarsipan data terutama dokumentasi surat perintah kerja pengadaan masih menggunakan pencatatan manual sehingga belum terdokumentasi dengan baik.

Dalam proses pengelolaan dokumen surat perintah kerja pengadaan BMKG masih belum maksimal salah satunya banyak yang tercecer atau terjadinya duplikasi data dan sering terjadi human error. Hal ini menjadi sebuah kendala atau masalah dalam hal peningkatan kualitas pengelolaan

JISICOM (Journal of Information System, Informatics and Computing) http://journal.stmikjayakarta.ac.id/index.php/jisicom Telp.+62-21-3905050, e-mail:jisicom@stmikjayakarta.ac.id, jisicom2017@gmail.com 


\section{Journal of Information System,}

Informatics and Computing

dokumentasi surat perintah kerja pengadaan terutama didalam era teknologi dan informasi.

Dengan sistem informasi yang terkomputerisasi, maka data-data pengolahan transaksi dan lainnya akan terkelola dengan baik, perencanaan dan keputusan-keputusan yang tepat serta efektif bisa disusun melalui data laporanlaporan yang tersaji. Pengarahan dan pengontrolan aktifitas-aktifitas bisnis dapat dilakukan dengan mudah, pelayanan yang cepat dan meminimalkan kecurangan manipulasi data dan kesalahan yang dilakukan oleh pegawai (human error) yang sering terjadi hampir disetiap divisi dengan menggunakan sistem secara manual.

\section{METODOLOGI} ini adalah :

Metodologi yang digunakan dalam penelitian

2.1 Teknik Pengumpulan Data

Teknik pengumpulan data yang digunakan yaitu : Observasi, wawancara dan studi pustaka

2.2 Model Pengembangan Sistem

Adapun model pengembangan sistem yang digunakan yaitu :

1. Analisa Kebutuhan Software

2. Desain

3. Code Generation

4. Testing

5. Support

\section{ANALISA SISTEM}

Proses bisnis dokumentasi surat perintah kerja pengadaan pada BMKG ini berawal dari Pejabat Pembuat Komitmen (PPK) mengajukan spesifikasi barang kepada Pejabat Pengadaan (PP). Kemudian PP melakukan review apakah ada kesalahan atau tidak dalam pembuatan spesifikasi barang kalau tidak PP akan menentukan dan menunjuk Penyedia. Penyedia disini adalah Pelaku Usaha yang menyediakan barang/jasa berdasarkan kontrak. Surat penawaran dibuat oleh penyedia yang ditunjuk dan langsung diajukan ke PP. Proses selanjutnya surat penawaran yang diperiksa oleh PP akan terjadi negosiasi harga atau tidak, jika iya maka penyedia membuat Surat Pernyataan Negosiasi dan PP membuat Surat Berita Acara Negosiasi, jika tidak maka PP akan membuatkan Laporan Hasil Pengadaan Langsung, lalu PPK akan membuat Surat Perintah Kerja (SPK) sebagai tindak lanjut dari Laporan Hasil Pengadaan Langsung dan membuat surat pesanan barang untuk penyedia. Setelah surat pesanan barang diterima maka penyedia segera mengirimkan barang beserta surat jalan, kwitansi dan faktur yang diterima langsung oleh PPK. Selanjutnya PPK merekap dan membuatkan laporan penerimaan barang kepada Pejabat Pengadaan setiap bulannya.

JISICOM (Journal of Information System, Informatics and Computing) http://journal.stmikjayakarta.ac.id/index.php/jisicom Telp.+62-21-3905050, e-mail:jisicom@stmikjayakarta.ac.id, jisicom2017@gmail.com 


\section{Journal of Information System, \\ Informatics and Computing}

Vol.4 No.2 Desember 2020

e-ISSN : 2597-3673 (Online)

p-ISSN : 2579-5201 (Printed)

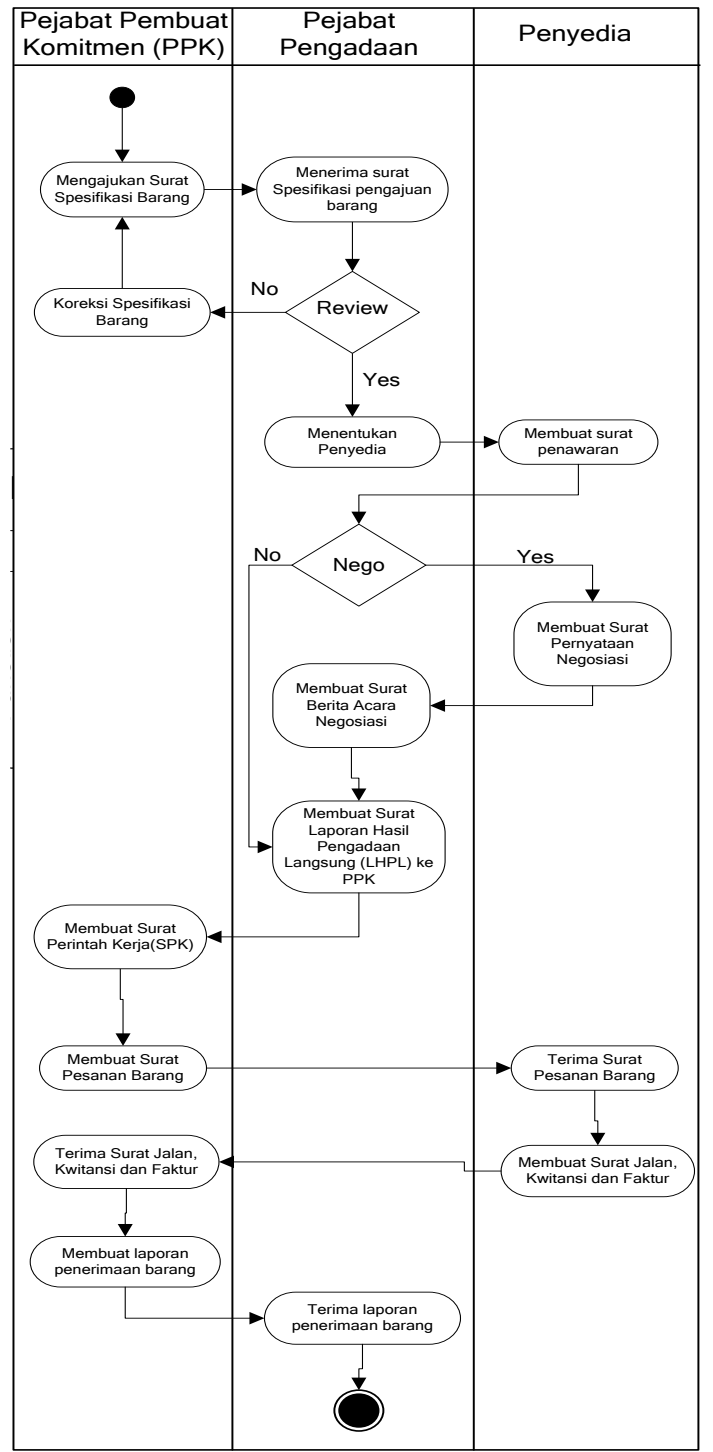

Gambar 1 Activity Diagram Bisnis Aplikasi

Pengadaan Barang dan Jasa Berbasis Web pada

BMKG

\section{Spesifikasi Dokumen Sistem Berjalan}

Spesifikasi dokumen sistem berjalan dibawah ini merupakan pembahasan mengenai bentuk dari dokumen-dokumen sistem berjalan yang dilakukan dalam proses spesifikasi barang karyawan.
Spesifikasi sistem berjalan tersebut terdiri dari dokumen masukan dan dokumen keluaran.

\section{A. Spesifikasi Bentuk Dokumen}

Spesifikasi bentuk dokumen terdiri dari dokumen masukan dan dokumen keluaran. Dokumen masukan diperlukan untuk memasukan data, sebelum data tersebut diolah menjadi informasi yang diperlukan yang disebut dengan dokumen keluaran. Dokumen-dokumen tersebut adalah sebagai berikut :

a) Dokumen Masukan :

Nama Dokumen : Surat Pengajuan Spesifikasi

$\begin{array}{ll}\text { Fungsi } & \begin{array}{l}\text { barang } \\ \text { : Untuk } \\ \text { pengadaaan barang } \\ \text { Sumber }\end{array} \\ \begin{array}{l}\text { Pejabat Pembuat } \\ \text { Komitmen }\end{array} \\ \text { Tujuan } & \text { Pejabat Pengadaan } \\ \text { Media } & : \text { Kertas } \\ \text { Frekuensi } & : \text { Setiap Pengadaan barang } \\ & \\ \text { Nama Dokumen } & \text { : Surat Penawaran } \\ \text { Fungsi } & : \text { Sebagai surat penawaran } \\ & \text { barang } \\ \text { Sumber } & : \text { Penyedia } \\ \text { Frekuensi } & : \text { Setiap ada pesanan barang } \\ \text { Tujuan } & : \text { Pejabat Pengadaan } \\ \text { Media } & : \text { Kertas }\end{array}$

b) Dokumen Keluaran :

Nama Dokumen : Surat Berita Acara Negosiasi

Fungsi : Sebagai surat hasil negosiasi dengan penyedia

Sumber : Pejabat Pengadaan

Frekuensi : : Setiap nego Surat Penawaran Penyedia

Tujuan : Pejabat Pembuat Komitmen (PPK)

Media $\quad:$ Kertas

Nama Dokumen : Laporan Hasil Pengadaan Langsung

Fungsi $\quad$ : Sebagai surat hasil pegadaan

Sumber $\quad$ : Pejabat Pengadaan

JISICOM (Journal of Information System, Informatics and Computing) http://journal.stmikjayakarta.ac.id/index.php/jisicom Telp.+62-21-3905050, e-mail:jisicom@stmikjayakarta.ac.id, jisicom2017@gmail.com 


\section{Journal of Information System, Informatics and Computing}

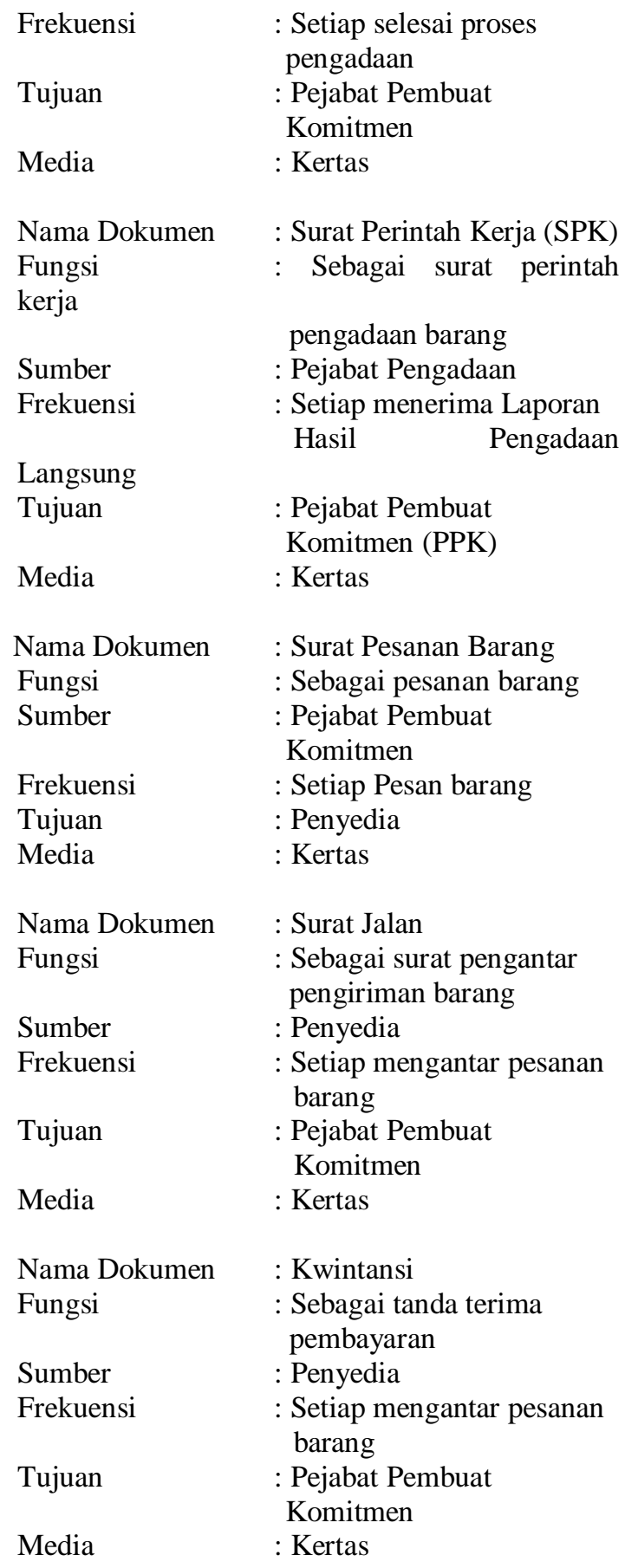

$\begin{array}{ll}\text { Nama Dokumen } & \text { : Faktur } \\ \text { Fungsi } & \text { : Sebagai surat tagihan } \\ & \text { pembayaran } \\ \text { Sumber } & \text { : Penyedia } \\ \text { Frekuensi } & \text { : Setiap mengantar pesanan } \\ & \text { barang } \\ \text { Tujuan } & \text { : Pejabat Pembuat } \\ & \text { Komitmen } \\ \text { Media } & \text { : Kertas }\end{array}$

\section{RANCANGAN SISTEM}

A. Use Case Diagram

Diagram use case menunjukan interaksi antara usecase actor dan aktivitas. Diagram ini menggambarkan model lengkap tentang apa yang dilakukan, siapa yang berperan didalamnya dan siapa orang yang berperan diluarnya. Berikut usecase usulan yang dibuat :

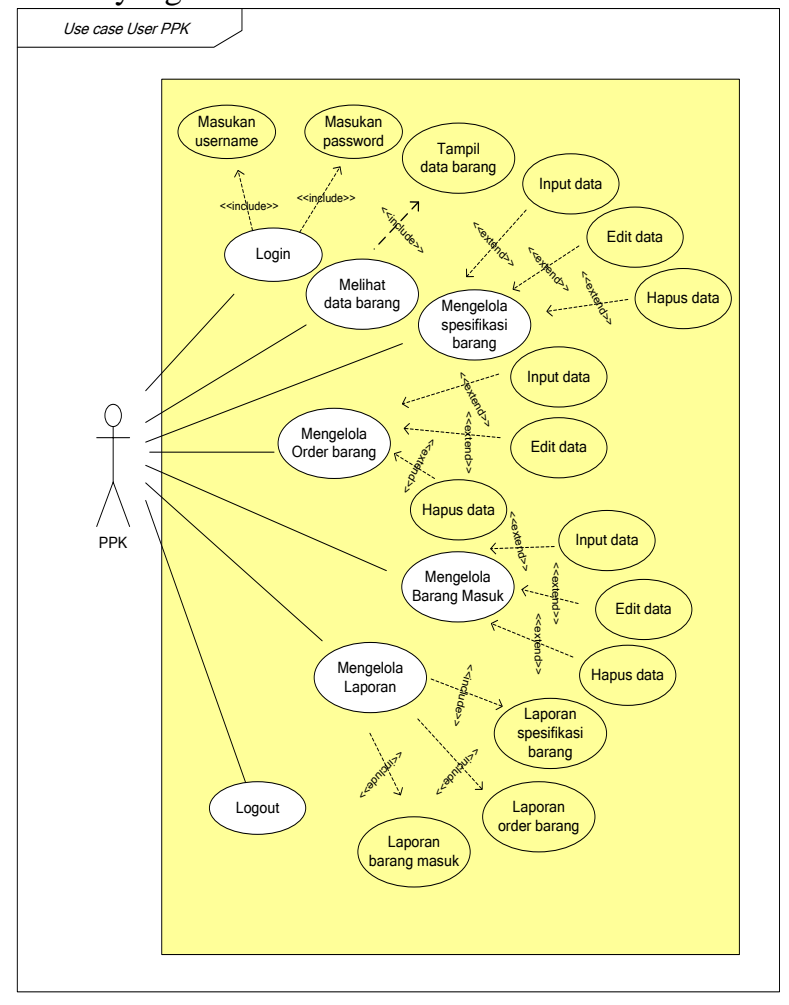

Gambar 2 Use Case Diagram PPK

JISICOM (Journal of Information System, Informatics and Computing) http://journal.stmikjayakarta.ac.id/index.php/jisicom Telp.+62-21-3905050, e-mail:jisicom@stmikjayakarta.ac.id, jisicom2017@gmail.com 


\section{Journal of Information System,}

\section{Informatics and Computing}

B. Activity diagram

1. Activity Diagram Spesifikasi Barang Halaman PPK.

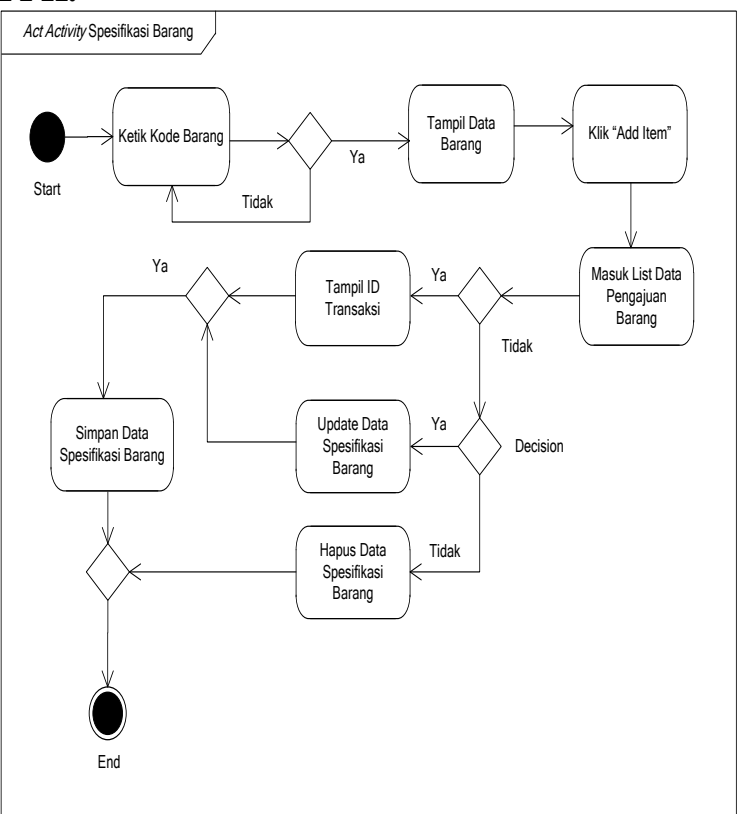

Gambar 3 Activity Diagram Order Barang Halaman PPK.

\section{Activity Diagram Admin Mengelola Data Barang}

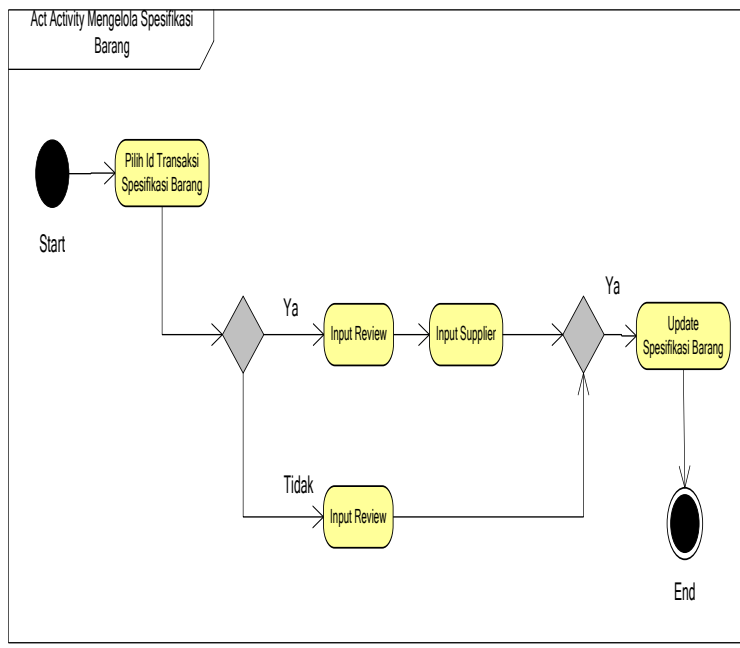

Gambar 4 Activity Diagram Admin Mengelola Spesifikasi Barang

\section{Database}

Database berfungsi untuk menggambarkan hubungan antar tabel yang dibuat beserta relasi antar tabel. Berikut gambaran database pada sistem yang dibuat :

\section{ERD (Entity Relationship Diagram)}

Entity Relationship Diagram berfiungsi untuk menggambarkan model basis data yang akan dipakai. Berikut adalah bentuk ERD dari perancangan sistem yang dibuat:

JISICOM (Journal of Information System, Informatics and Computing) http://journal.stmikjayakarta.ac.id/index.php/jisicom Telp.+62-21-3905050, e-mail:jisicom@stmikjayakarta.ac.id, jisicom2017@gmail.com 


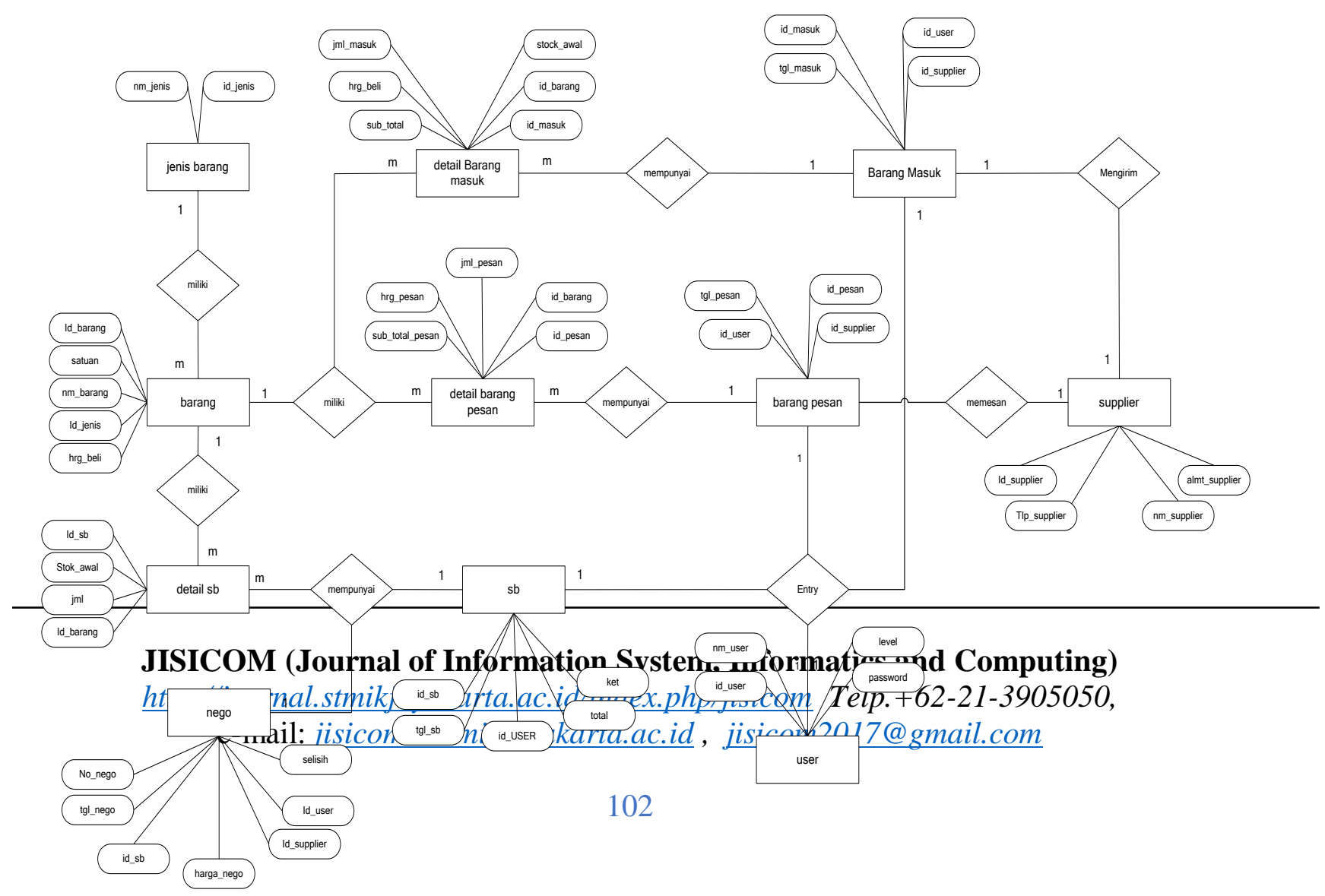


2. LRS (Logical Record Structure)

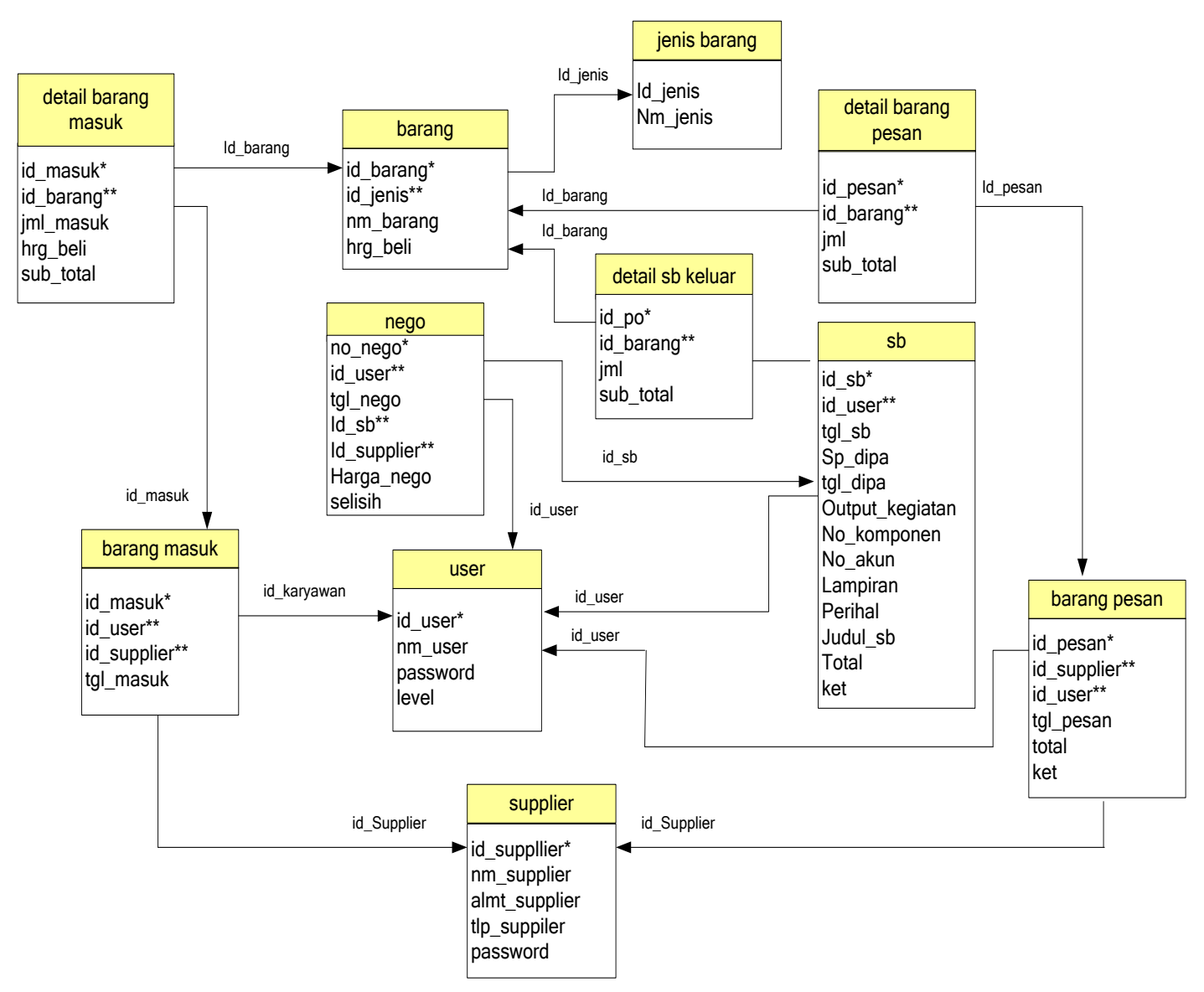

JISICOM (Journal of Information System, Informatics and Computing) http://journal.stmikjayakarta.ac.id/index.php/jisicom Telp.+62-21-3905050, e-mail:jisicom@stmikjayakarta.ac.id, jisicom2017@gmail.com 
Gambar 6. Logical Record Structure

JISICOM (Journal of Information System, Informatics and Computing) http://journal.stmikjayakarta.ac.id/index.php/jisicom Telp.+62-21-3905050, e-mail: jisicom@stmikjayakarta.ac.id, jisicom2017@gmail.com 


\section{Journal of Information System, Informatics and Computing}

\subsubsection{Software Architecture}

1. Component Diagram

Component diagram menggambarkan struktur dan hubungan antar komponen piranti lunak, termasuk ketergantungan (dependency) diantaranya.

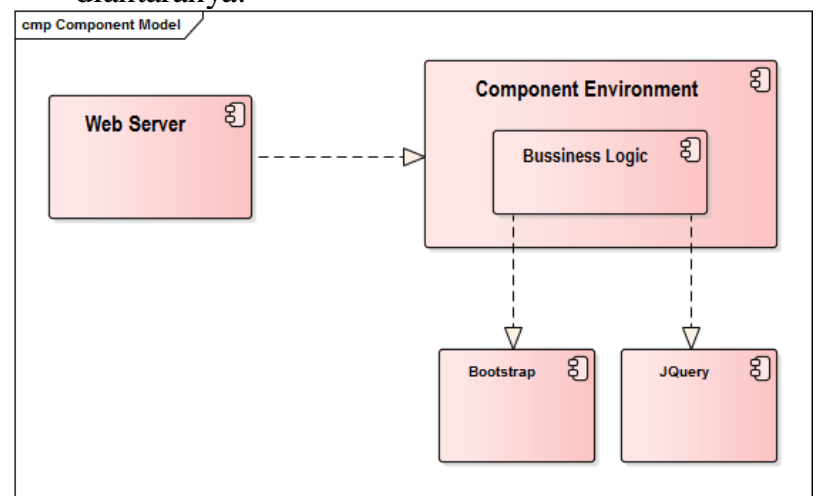

Gambar 7 Component Diagram

\section{Deployment Diagram}

Deployment diagram menggambarkan detail bagaimana komponen di-deploy dalam infrastruktur sistem, dimana komponen akan terletak pada mesin, server, dan piranti keras lainnya.

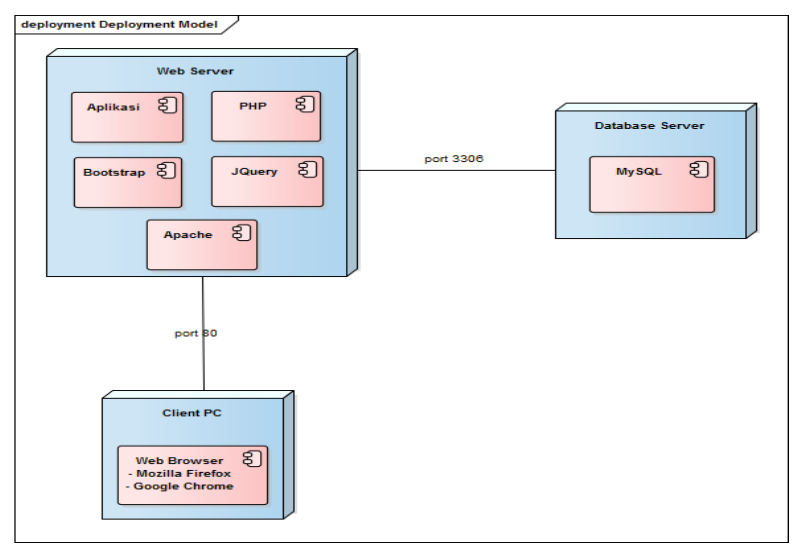

Gambar 8 Deployment Diagram

a. Client Browser : Software yang berfungsi menampilkan dan melakukan interaksi dengan dokumen-dokumen yang disediakan oleh server web. Contoh : Mozilla Firefox, Internet
Explorer, Opera.

b. Web Server: Sebuah software yang memberikan layanan data yang berfungsi menerima permintaan HTTP atau HTTPS dari client dikenal dengan browser dan mengirimkan kembali hasilnya dalam bentuk halaman. Contoh : Apache.

c. Database Server : Program Komputer yang menyediakan layanan data lainnya ke computer atau program computer. Contoh : MySQL.

\subsubsection{User Interface}

Sebuah website yang dinamis biasanya memiliki dua jenis tampilan website yaitu halaman frontend dan halaman backend. Halaman frontend itu adalah halaman utama website yang dapat diakses oleh banyak pengujung, sedangkan halaman backend adalah sebagai halaman kontrol yang mengatur content dari halaman utama yang dapat diakses oleh Admin website.

$$
\text { Berikut tampilan program dari sistem }
$$
usulan :

\section{Halaman Login}

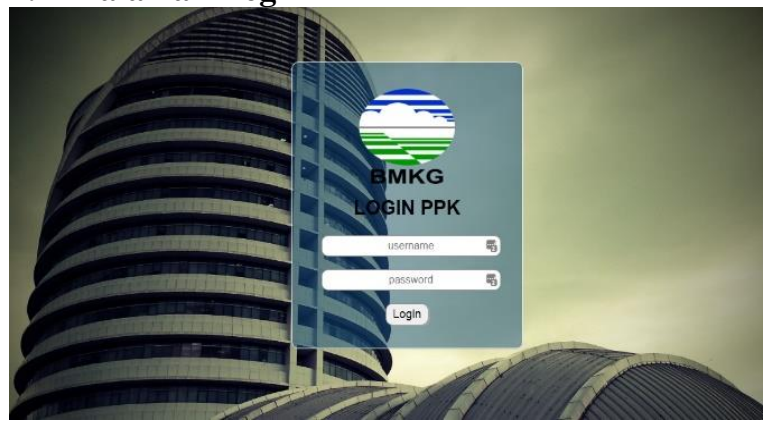

Gambar 9 Tampilan Halaman Login PPK

\section{Halaman Dashboard PPK}

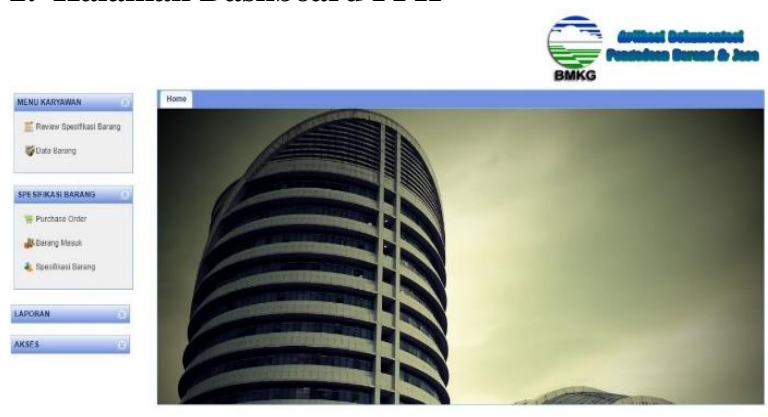

JISICOM (Journal of Information System, Informatics and Computing) http://journal.stmikjayakarta.ac.id/index.php/jisicom Telp.+62-21-3905050, e-mail:jisicom@stmikjayakarta.ac.id,jisicom2017@gmail.com 


\section{Journal of Information System, Informatics and Computing}

Vol.4 No.2 Desember 2020 e-ISSN : 2597-3673 (Online) p-ISSN : 2579-5201 (Printed)

Gambar 10 Tampilan Halaman Dashboard PPK

\section{Halaman Pengajuan Spesifikasi Barang PPK}

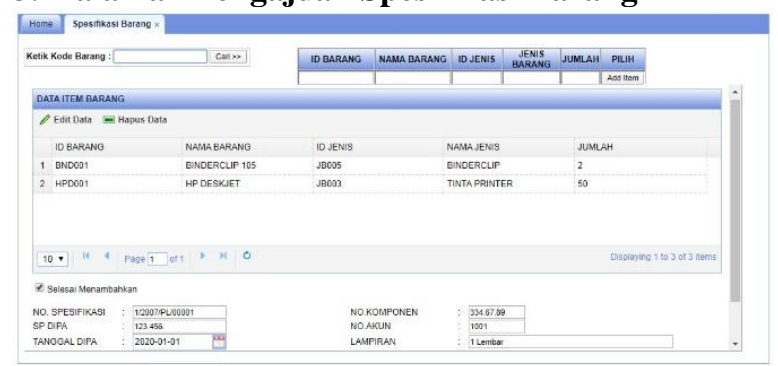

Gambar 11 Tampilan Halaman Pengajuan Spesifikasi Barang

\section{Halaman Print Out Spesifikasi Barang PPK}

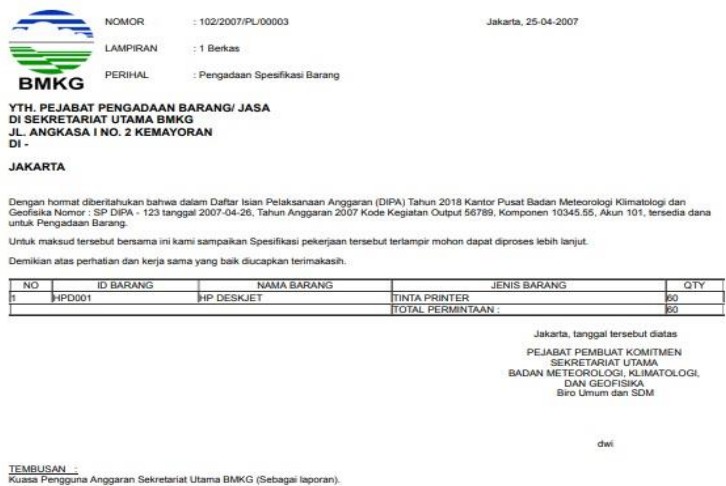

Gambar 12 Tampilan Halaman Print Out Spesifikasi Barang

\section{Halaman Review Pengajuan Spesifikasi Barang} PPK

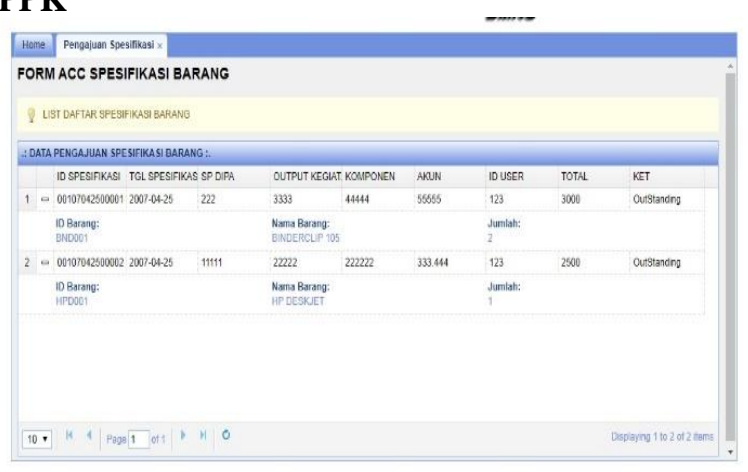

Gambar 13 Tampilan Halaman Review Pengajuan Spesifikasi Barang

\section{Halaman Login Admin}

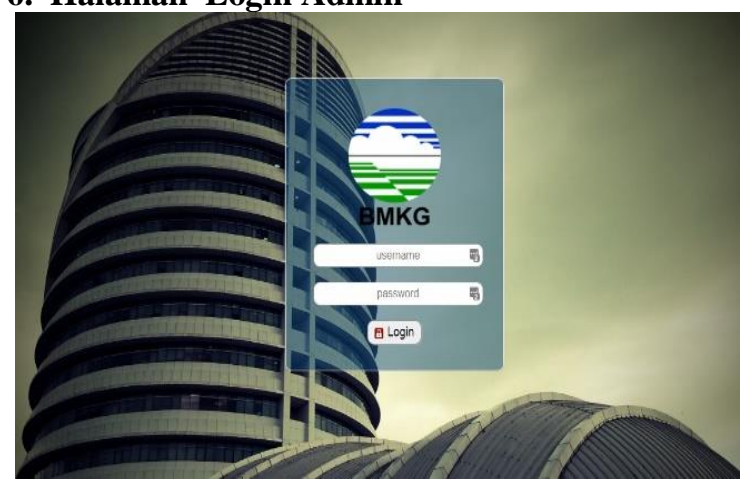

Gambar 14 Tampilan Halaman Login Admin

5. Halaman Beranda Admin

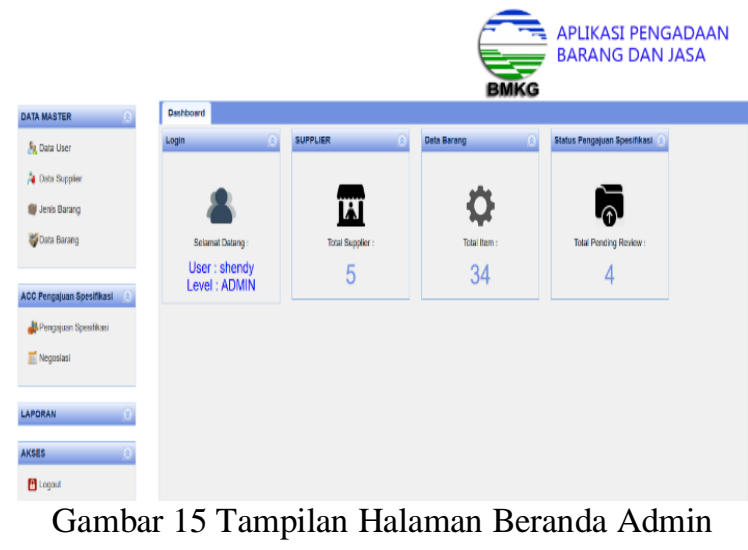

7. Halaman Data Barang

JISICOM (Journal of Information System, Informatics and Computing) http://journal.stmikjayakarta.ac.id/index.php/jisicom Telp.+62-21-3905050, e-mail: jisicom@stmikjayakarta.ac.id, jisicom2017@gmail.com 


\section{Journal of Information System, Informatics and Computing}

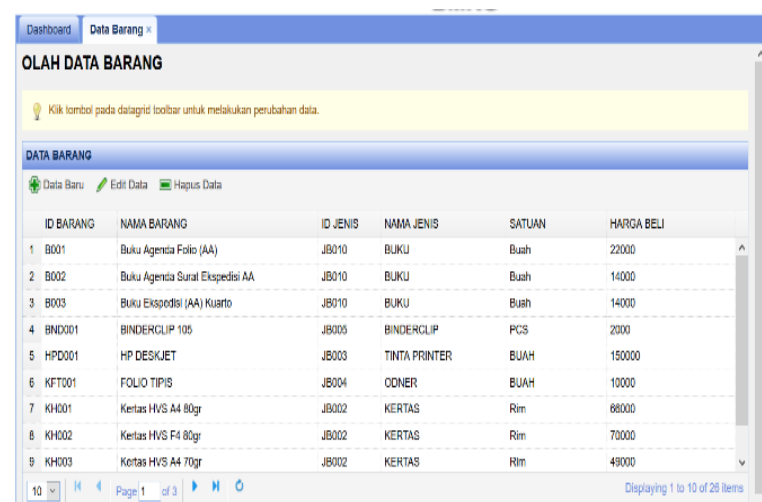

Gambar 16 Tampilan Halaman Data Barang

\section{Halaman Data Jenis Barang}

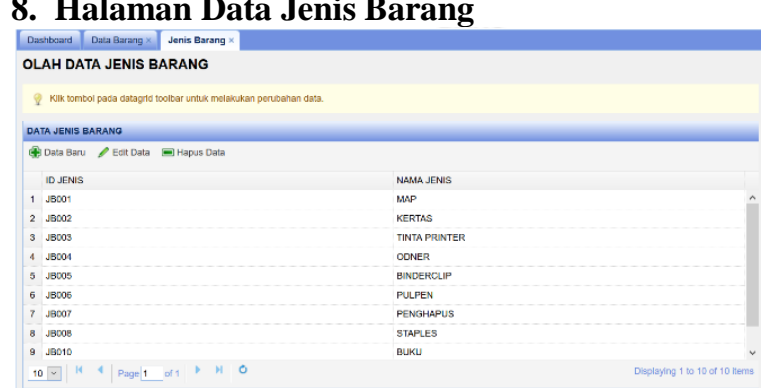

Gambar 17 Tampilan Halaman Data Jenis Barang

\section{Halaman Data Supplier}

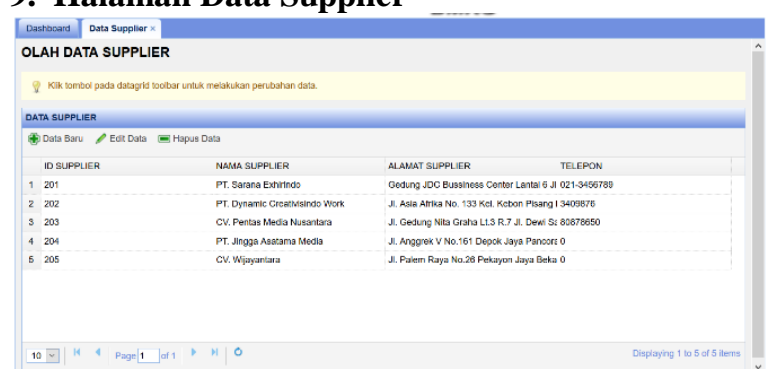

Gambar 18 Tampilan Halaman Data Supplier

10. Halaman Persetujuan Spesifikasi Barang

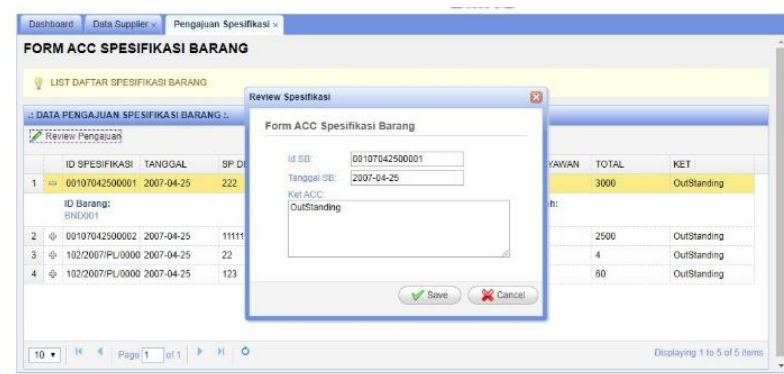

Gambar 19 Tampilan Halaman Persetujuan Spesifikasi Barang

\section{Halaman Output Nego}

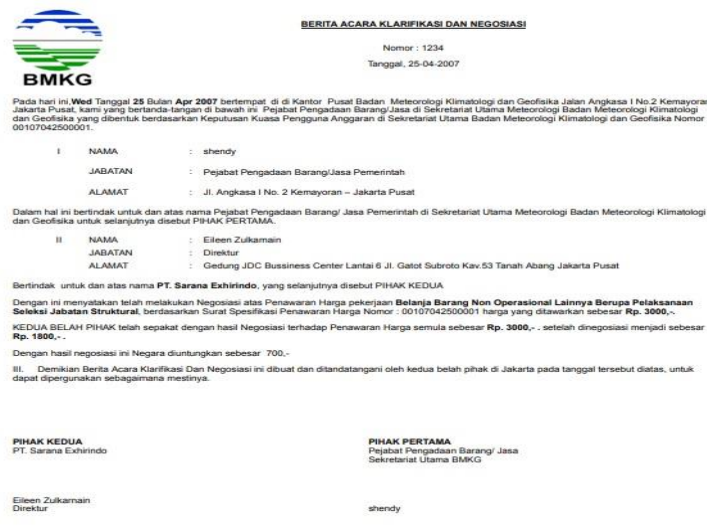

Gambar 20 Tampilan Halaman Output Nego

12. Halaman Form Nego

JISICOM (Journal of Information System, Informatics and Computing) http://journal.stmikjayakarta.ac.id/index.php/jisicom Telp.+62-21-3905050, e-mail: jisicom@stmikjayakarta.ac.id,jisicom2017@gmail.com 


\section{Journal of Information System, Informatics and Computing}

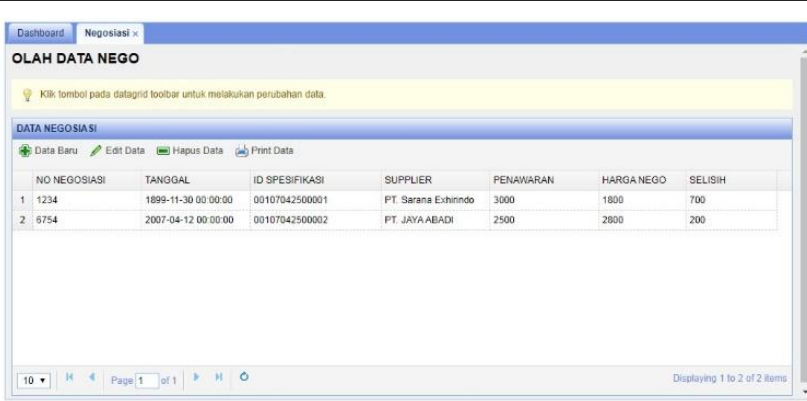

Gambar 21 Tampilan Halaman Form Nego

\section{Halaman Laporan Barang \\ a. Laporan Barang Masuk}

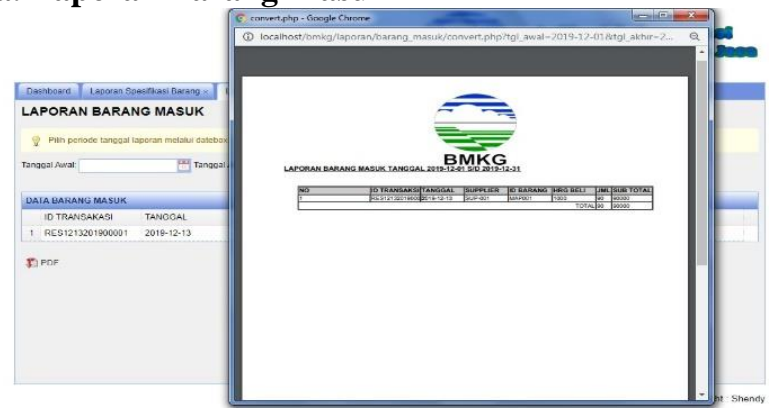

Gambar 22 Tampilan Halaman Laporan Barang Masuk

\section{b. Laporan Spesifikasi Barang}

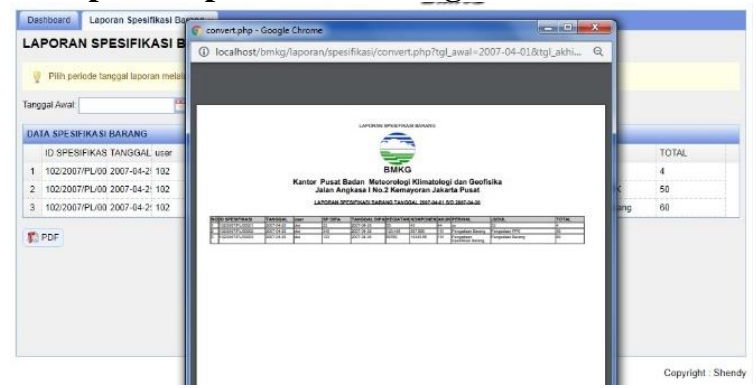

Gambar 23 Tampilan Halaman Laporan Spesifikasi Barang

\section{c. Laporan Stok Barang}

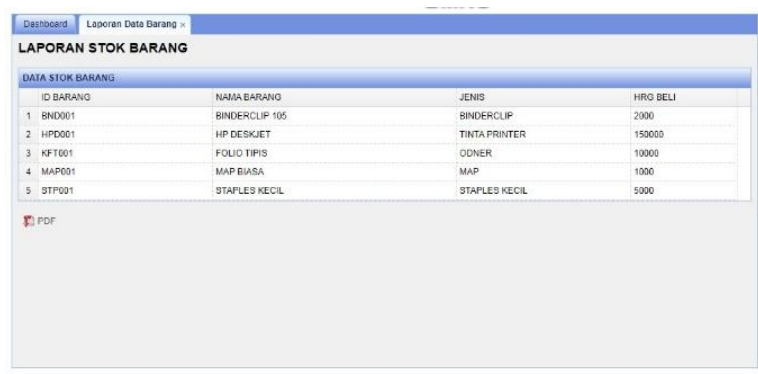

Gambar 24 Tampilan Halaman Laporan Stok Barang

\section{KESIMPULAN}

Adapun kesimpulan dari penelitian ini adalah sebagai berikut :

1. Aplikasi Pengadaan Barang dan Jasa berbasis web ini, dapat mempermudah Pejabat Pengadaan (PP) dan Pejabat Pembuat Komitmen (PPK) dalam proses manajemen dokumen pengadaan dan pembuatan laporan dengan menggunakan bahasa pemrograman PHP dan MySQL sebagai database.

2. Desain Aplikasi Pengadaan Barang dan Jasa berbasis web ini terlihat user friendly

3. Dapat mempercepat proses pengadaan barang dan jasa.

4. Dapat mempercepat proses pembuatan laporan bulanan.

5. Sistem yang dirancang menggunakan 2 hak akses yang diberikan kepada Admin, dan User.

\section{REFERENSI}

[1] Aji, Sapto; Migunani; Nur Hakim, F. (2014). Rancang Bangun Sistem Informasi Disposisi Surat Berbasis Web, 3(3), 25-32.

[2] Anwar, S., \& Irawan, F. (2017). Rancang Bangun Sistem Informasi Pengajuan Pengadaan Suku Cadang Mobil Pada Pt. Andalan Chrisdeco Berbasis Web. Pilar Nusa Mandiri, 13(1), 113-121. https://doi.org/1978-1946

[3] Atmoko, Y. D., \& Arizona, N. D. (2016). Aplikasi Penjualan dan Pembelian Secara Tunai dan Non Tunai Pada PD Istana Gypsum

JISICOM (Journal of Information System, Informatics and Computing) http://journal.stmikjayakarta.ac.id/index.php/jisicom Telp.+62-21-3905050, e-mail: jisicom@stmikjayakarta.ac.id,jisicom2017@gmail.com 
Pontianak. Simnasiptek 2016, 1(1), 38-44.

[4] Basri, H., Alfarizi, S., Mulyawan, A. R., Wiguna, A., \& Habiba, I. (2019). PERANCANGAN SISTEM INFORMASI BOOKING PEREKAMAN E-KTP ( SI MBOK ) BERBASIS WEB, 15(1), 69-76.

[5] Fitriani, E., Firmansyah, D., Aryanti, R., \& Walim. (2018). IMPLEMENTASI MODEL WATERFALL PADA SISTEM INFORMASI AKADEMIK BERBASIS WEB PADA SMK PERTANIAN KARAWANG. Jurnal Techno Nusa Mandiri, 15(2), 137-144.

[6] Hastanti, R. P., Eka, B., Indah, P., \& Wardati, U. (2015). Sistem Penjualan Berbasis Web ( ECommerce ) Pada Tata Distro Kabupaten Pacitan, 3(2), 1-9.

[7] Hendini, A. (2016). No Title, IV(2), 107-116.

[8] Hutahaean, J. (2015). Konsep Sistem Informasi. Deepublish.

[9] Indarti, \& Laraswati, D. (2018). Rancang Bangun Sistem Informasi Pelayanan Kesehatan Berbasis Web Pada Klinik Umum Galur Medika Jakarta Pusat. Jurnal Teknik Komputer, IV(2), 71-76. https://doi.org/10.31294/jtk.v4i2.3549

[10] Indiharto, R. A., Hilda, A. M., \& Avorizano, A. (2016). Perancangan Sistem Informasi InventoryBarang Berbasis Web pada Perusahaan Pergudangan, 38-48.

[11] Indrajani. (2018). Database Systems All in One Theory, Practice, and Case Study. Elex Media Komputindo.

[12] Journal, I. (2014). IJNS - Indonesian Journal on Networking and Security - Volume 3 No 3 Juli 2014 - ijns.org, 3(3), 25-32.

[13] Julianti, R., Budiman, A., \& Sopyan, A. (2017). Sistem Monitoring Pengajuan Pembangunan Infrastruktur Berbasis Web pada KopSyah BMI Cabang Tangerang 2, 7(2).

[14] Mulyani, S. (2016). Metode Analisis dan Perancangan Sistem. Abdi Sistematika.

[15] Nazir, N., \& Darmawati, G. (2018). PERANCANGAN PENCATATAN DAN PELAPORAN TERPADU PUSKESMAS BERBASIS E-REPORT UNTUK MENINGKATKAN, 18(2).
[16] Nurcahyo, Widyat; Agustina, Y. (2016). Pengembangan Sistem Informasi Berbasis Web Penatausahaan Keuangan SKPD pada Proses SPP-SPM, XI, 189-200.

[17] Patma, T. S., Maskan, M., \& Utaminingsih, A. (2018). Sistem Informasi Manajemen Guna Mendukung Keputusan. Polinema Press.

[18] Prabowo, D. (2015). WEBSITE ECOMMERCE MENGGUNAKAN MODEL VIEW CONTROLLER ( MVC) DENGAN FRAMEWORK CODEIGNITER Studi Kasus : Toko Miniatur Pendahuluan Landasan Teori, 16(1), 23-29.

[19] Prayitno, A., \& Safitri, Y. (2015). Pemanfaatan Sistem Informasi Perpustakaan Digital Berbasis Website Untuk Para Penulis. Indonesian Journal on Software Engineering, 1(1), 1-10.

[20] Puspitasari, D. (2016). Sistem informasi perpustakaan sekolah berbasis web, (2), 227240.

[21] Rahmah, D. L. (2014). PERANCANGAN APLIKASI SISTEM PERSURATAN BERBASIS WEB PADA PT . DWI PILAR PRATAMA, 7(3), 282-292.

[22] Rahman, B. (n.d.). Sistem Monitoring Kinerja PNS Dengan Aplikasi SKP Berbasis WEB, 1349-1358.

[23] Ramanda, K., Komarudin, R., Maisyaroh, \& Agus, S. (2014). Rancang Bangun Sistem Informasi Simpan Pinjam Pada Koperasi, 1116.

[24] Rusdiansyah; (2019). Membangun Prototype Sistem Informasi Arsip Elektronik Surat Perjanjian Kerjasama Pada Business Support Departement. Jurnal Pilar Nusa Mandiri, 14(2), 157. https://doi.org/10.33480/pilar.v14i2.903

[25] Sari, D. P. (2019). PERENCANAAN EPROCUREMENT DALAM PENGADAAN, 9(April), 29-38.

[26] Sega, P., \& Safarudin, M. S. (2017). Program Studi Sistem Informasi, Manajemen Informatika, Dan Teknik Komputer Fakultas Teknik Universitas Batam, 7.

[27] Siregar, H. F., Siregar, Y. H., \& Melani. (2018).

JISICOM (Journal of Information System, Informatics and Computing) http://journal.stmikjayakarta.ac.id/index.php/jisicom Telp.+62-21-3905050, e-mail:jisicom@stmikjayakarta.ac.id, jisicom2017@gmail.com 


\section{Journal of Information System,}

\section{Informatics and Computing}

Vol.4 No.2 Desember 2020

e-ISSN : 2597-3673 (Online)

p-ISSN : 2579-5201 (Printed)

Perancangan Aplikasi Komik Hadist Berbasis

Multimedia. Teknologi Informasi, 2(2), 113-

121.

[28] Sitohang, H. T. (2018). SISTEM INFORMASI

PENGAGENDAAN SURAT BERBASIS, 3(1), 6-9.

[29] Somya, R., \& Nathanael, T. M. E. (2019). Pengembangan Sistem Informasi Pelatihan Berbasis Web Menggunakan Teknologi Web Service Dan Framework Laravel, 16(1), 51-58.

[30] Sujarweni, V. W. (2015). Metodologi Penelitian. Pustaka Baru Press.

[31] Syamwil, D. R., \& Febiharsa, D. (2018). Sistem Informasi Lembaga Sertifikasi Profesi. Penerbit Cerdas Ulet Kreatif.

[32] Yanosma, Delfi; Johar T, Asahar; Anggriani, K. (2016). IMPLEMENTASI METODE KNEAREST NEIGHBOR ( KNN ) DAN SIMPLE ADDITTIVE WEIGHTING ( SAW ) DALAM PENGAMBILAN KEPUTUSAN SELEKSI PENERIMAAN ANGGOTA PASKIBRAKA, 222-235.

[33] Yatini B, I. (2015). Aplikasi pengolahan citra berbasis web menggunakan javascript dan jquery, 1-8.

JISICOM (Journal of Information System, Informatics and Computing) http://journal.stmikjayakarta.ac.id/index.php/jisicom Telp.+62-21-3905050, e-mail:jisicom@stmikjayakarta.ac.id, jisicom2017@gmail.com 